\title{
From the Affordable Care Act to Affordable Care
}

\section{Citation}

Cutler, David M. 2015. "From the Affordable Care Act to Affordable Care." JAMA 314 (4) (July 28): 337. doi:10.1001/jama.2015.7683.

\section{Published Version}

doi:10.1001/jama.2015.7683

\section{Permanent link}

http://nrs.harvard.edu/urn-3:HUL.InstRepos:27074176

\section{Terms of Use}

This article was downloaded from Harvard University's DASH repository, and is made available under the terms and conditions applicable to Other Posted Material, as set forth at http:// nrs.harvard.edu/urn-3:HUL.InstRepos:dash.current.terms-of-use\#LAA

\section{Share Your Story}

The Harvard community has made this article openly available.

Please share how this access benefits you. Submit a story.

Accessibility 
VIEWPOINT

David M. Cutler, PhD Department of Economics, Harvard University, Cambridge, Massachusetts.
Corresponding Author: David M. Cutler, PhD, Department of Economics, Harvard University, 1805 Cambridge St, Cambridge, MA 02138 (dcutler@harvard.edu).

\section{From the Affordable Care Act to Affordable Care}

Health reform is a process, not a destination. The Affordable Care Act (ACA) will not be the last word in health policy any more than were Medicare and Medicaid. The ACA focused primarily on extending insurance coverage. Going forward, policy will need to address 2 areas the ACA pursued less vigorously: continuing to slow the increase in health costs and improving the practice environment for physicians.

\section{Continuing the Push for Cost Reductions}

The single most important issue in health care is eliminating unnecessary medical spending. Health costs have traditionally increased at $1 \%$ to $2 \%$ annually above the growth of the economy. Long-term financial security requires the growth in cost to slow to economic growth or less. With about one-third of medical spending estimated to be wasted, achieving lower growth is technically possible. ${ }^{1}$ The question is how to make it happen.

There are 2 broad strategies for cost savings, both receiving extensive testing: transforming medical payments from volume based to value based and encouraging insurance policies to require greater out-ofpocket costs. The payment reform approach is based on the idea that the volume of services has increased so

\section{Pay for value, not volume, and waste} will be eliminated.

substantially because the price paid for more intensive services is so high. Pay for value, not volume, and waste will be eliminated.

Medicare's accountable care organization (ACO) program is the most noted value-based program, but there are others. Medicare and private payers are experimenting with paying for episodes of care rather than for each interaction. Even for fee-for-service payments, physicians and hospitals already or soon will face penalties for medical errors and excessive readmissions.

Studies examining the effect of value-based payment strategies have been positive. The Pioneer ACO program and comparable private programs have demonstrated cost savings and quality improvements. ${ }^{2,3}$ Similarly, readmission rates are declining with the Medicare penalty, and health care-acquired infections are declining as payers stop reimbursing these costs.

One post-ACA strategy is to significantly expand the use of value-based payment models. The federal government has set a goal for $50 \%$ of Medicare payments to be made on a non-fee-for-service basis by 2018 , with nearly all remaining fee-for-service payments tied to outcomes. Private-sector groups have made similar proposals. Congress is in agreement, too; the Sustainable Growth Rate formula was replaced by a program requiring greater use of value-based payments for physicians.

The central need at this point is to manage the transition from volume- to value-based payment. Designing, evaluating, and modifying payment formulas are complex activities, and federal agencies have little experience with such transformations. The last time the Department of Health and Human Services moved outside its area of expertise-when it designed and built the federal health insurance exchanges-it made substantial mistakes. Avoiding a repeat of that outcome will require serious attention to management and policy.

\section{Information and Incentives for Chronic Care} Management

High cost sharing is the second strategy in cost reduction. The idea is that people with money at stake will make better care choices than people who pay little of the cost. High cost-sharing plans have quietly become the norm. An estimated $20 \%$ of people with private insurance have a deductible of $\$ 2500$ or higher, and the most common plans in the ACA exchanges have deductibles that are even greater.

Empirical studies on behavior show that total spending declines by $5 \%$ to $14 \%$ when people join high cost-sharing plans. ${ }^{4}$ The major concern is that the reduction in service use is haphazard; people choose to reduce valuable services as well as less valuable ones.

Part of the reason that people reduce utilization indiscriminately is because they do not know their options for less expensive care. If a physician recommends magnetic resonance imaging but the recommended imaging center is out of network, people have little ability to know where they can find an in-network imaging center. Insurers could provide this information, but most insurers have chosen not to invest in the systems required to do so. Federal policy might require insurers to provide price and quality information to enrollees. This could be done through legislation (as in Massachusetts) or by having the availability of real-time information be a precondition for an insurer to be listed on federal exchanges.

Information provision will only go so far, however. Even when people know what services they need and can seek low prices, high cost sharing deters use. In a recent survey, $23 \%$ of insured people reported skipping needed medical care because of costs. ${ }^{5}$ The missed care has up-front costs-medications, tests, and visits-but may have long-term health benefits.

The quest for cost savings should not compromise health. One model to avoid discouraging necessary care is provided by the preventive service provisions in the 
ACA, which require insurers to cover preventive care at no cost sharing. The same could be done for chronic care services. A federal body could be made responsible for compiling a list of services (1) that help manage chronic disease, (2) that are clearly effective, and (3) for which there is evidence that price is a significant barrier to use. Such services would then be covered at no out-of-pocket cost.

\section{Protection From Unforeseen Risk}

Insurers are not the only ones at fault. Some physicians contribute to the problem by purposely making their services out of network. For example, the facility fee at an emergency department might be covered by insurance, but not the fee of the attending physician. Or a primary surgeon might be in network, but an assistant surgeon might not. In such a situation, the entire bill for the out-of-network physician becomes the responsibility of the patient. Patients struggle to pay; many become bankrupt.

These gaps in coverage must be addressed for people to manage their health. One possibility is to impose a rule such that in settings where a patient has no ability to consent, out-of-pocket costs for patients must be limited to the amount the patient would pay for comparable in-network care. The insurer would then pay the remainder, but at in-network rates. A number of states are working on legislation that would resolve this issue; federal efforts could extend this nationally.

\section{Malpractice and Administrative Reform}

Physician practices are under strain. Physicians are being asked to assume more financial risk, invest in electronic medical record systems, and meet quality guidelines. Although all of these requirements are valuable, policy cannot simply add to the burden on physicians.

Two areas of medicine are in need of reform: malpractice liability and administrative costs. Three to twenty percent of physicians will be sued for malpractice in any year, and more than threequarters will be sued in their lifetime. ${ }^{6}$ Malpractice suits cost money and also make physicians wary about adjusting to system changes. A major direction for reform must be to ensure that physicians who adhere to guideline standards know that lawsuits based on providing that care will be rapidly dismissed.

Administrative costs are equally troubling. Physicians in the United States spend time and money interacting with health plans about payment, dealing with formularies, and obtaining authorizations for procedures. The United States spends more on administrative costs than on heart disease and cancer combined. ${ }^{7}$ In most industries, administrative costs decline when largemarket participants push for standardized practices. For example, Walmart forced retail suppliers to communicate more efficiently; administrative costs decreased throughout the retail sector. The obvious analog is for the federal government to enforce standardization of administrative transactions. Such an effort would improve care and reduce spending.

The ACA is a major step in the century-long quest to guarantee insurance coverage to all US residents. However, innovation is necessary to ensure future success. What comes next must be a focus on ensuring that the money to pay for health care is neither wasted nor cut short because the resources cannot be found.

\section{ARTICLE INFORMATION}

Conflict of Interest Disclosures: The author has completed and submitted the ICMJE Form for Disclosure of Potential Conflicts of Interest. Dr Cutler reports receiving honoraria, speaking fees, book royalties, and payment for referee reports, white papers, travel and living expenses from numerous organizations, institutions, and companies. He is a consultant to Kyruus and receives a small amount of its stock. He is a grant recipient from the National Institutes of Health.

\section{REFERENCES}

1. Berwick DM, Hackbarth AD. Eliminating waste in US health care. JAMA. 2012;307(14):1513-1516.

2. Nyweide DJ, Lee W, Cuerdon TT, et al. Association of Pioneer accountable care organizations vs traditional Medicare fee for service with spending, utilization, and patient experience [published online May 4, 2015]. JAMA. 2015;313(21): 2152-2161.

3. Song Z, Rose S, Safran DG, Landon BE, Day MP, Chernew ME. Changes in health care spending and quality 4 years into global payment. $N$ Engl J Med. 2014:371(18):1704-1714.
4. Bundorf MK. Consumer-Directed Health Plans: Do They Deliver? Princeton, NJ: Robert Wood Johnson Foundation; October 2012

5. Collins SR, Rasmussen PW, Doty MM, Beutel S. Too High a Price: Out-of-Pocket Health Care Costs in the United States. New York, NY: Commonwealth Fund; November 13, 2014.

6. Mello MM, Studdert DM, Kachalia A. The medical liability climate and prospects for reform. JAMA. 2014:312(20):2146-2155.

7. Cutler D, Wikler E, Basch P. Reducing administrative costs and improving the health care system. N Engl J Med. 2012;367(20):1875-1878. 